Goldschmidt 2021 Abstract

https://doi.org/10.7185/gold2021.4626

\section{Alteration of spodumene to muscovite and cookeite - implications for the fate of Lithium and Iron}

MR. JOHANNES CHISCHI ${ }^{1}$, HANS C. OSKIERSKI ${ }^{1}$, MAHMOUD F. ALHADAD ${ }^{1}$, ARTUR DEDITIUS ${ }^{1}$, GAMINI SENANAYAKE ${ }^{2}$, MALCOLM P. ROBERTS ${ }^{3}$ AND BOGDAN

\section{Z. DLUGOGORSKI ${ }^{4}$}

${ }^{1}$ Harry Butler Institute, Murdoch University

${ }^{2}$ Murdoch University

${ }^{3}$ University of Western Australia

${ }^{4}$ Charles Darwin University

Presenting Author: Johannes.Chischi@murdoch.edu.au

Post-ore alteration of spodumene in LCT pegmatites affects the chemical and mineralogical composition and, consequently, the quality of spodumene ores. However, the mechanism of alteration and the effect on spodumene grade and processing are poorly understood.

Here we present the mineralogy and mineral chemistry of spodumene samples of white, grey, yellow, green, and dark green colour, representing five stages of spodumene alteration at the Bald Hill mine in the Eastern Goldfields of Western Australia. White and grey spodumene show little impurities and their composition is close to stoichiometric $\mathrm{LiAlSi}_{2} \mathrm{O}_{6}$. Fine-grained muscovite veins aligned with cleavage planes are present in yellow spodumene specimens. Green and dark green samples contain assemblages of spodumene + muscovite + cookeite + quartz \pm microcline and muscovite + cookeite, respectively, which replace the original spodumene. Two types of muscovite are present, one dark $\left(\mathrm{Li}_{2} \mathrm{O} \sim 4.5, \mathrm{Al}_{2} \mathrm{O}_{3}=31.2, \mathrm{~K}_{2} \mathrm{O}=6.4\right.$, $\mathrm{Fe}_{2} \mathrm{O}_{3}=1.4, \mathrm{MgO}=2.6$ wt. $\left.\%\right)$ and one bright $\left(\mathrm{Li}_{2} \mathrm{O} \sim 1.5, \mathrm{Al}_{2} \mathrm{O}_{3}\right.$ $=26.4, \mathrm{~K}_{2} \mathrm{O}=9.6, \mathrm{Fe}_{2} \mathrm{O}_{3}=4.3, \mathrm{MgO}=3.9$ wt. \%) in BSE images (Fig. 1), with cookeite predominantly associated to the latter.

Breakdown of primary microcline provided $\mathrm{K}$ for the crystallisation of muscovite during replacement of spodumene in acidic fluids. Dark muscovite contains $\mathrm{Al}$ and $\mathrm{Li}$ from spodumene breakdown, whereas bright muscovite is enriched in fluid-transported $\mathrm{K}$. Additional $\mathrm{Fe}$ and $\mathrm{Mg}$ enrichment in muscovite and cookeite suggest that fluids interacted with the mafic country rock before pegmatite alteration and chloritisation. Alteration to yellow, green, and dark green specimens lowers ore value due to low Li content, additional challenges in liberation and flotation, as well as higher $\mathrm{Fe}$ contents associated with undesired clinker formation during calcination.

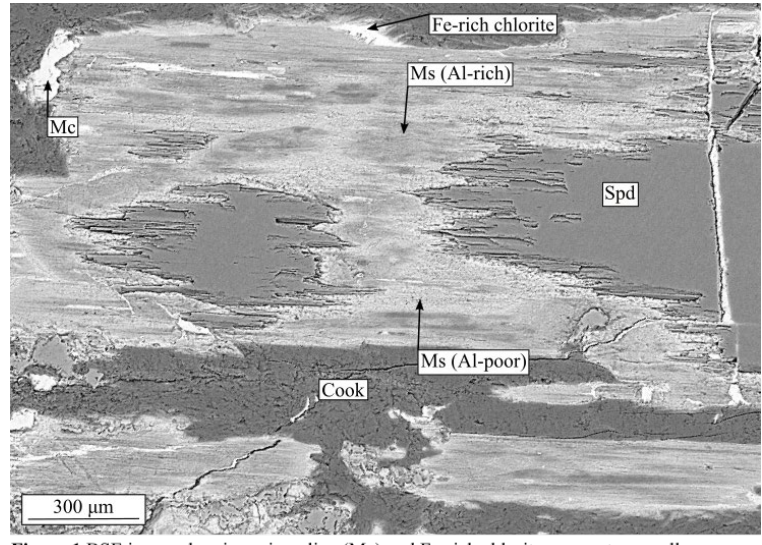

Figure $1 \mathrm{BSE}$ image showing microcline (Mc) and Fe-rich chlorite remnants as well as spodumene (Spd) alteration to Al-rich (dark) and poor (bright) muscovite (Ms) intergrown with cookeite (Cook). 